\title{
Occurrence of Cryptosporidium spp. and Giardia spp. in a public water-treatment system, Paraná, Southern Brazil
}

\author{
Ocorrência de Cryptosporidium spp. e Giardia spp. em uma estação pública de tratamento de água, \\ Paraná, Sul do Brasil \\ Jonatas Campos Almeida ${ }^{1}$; Felippe Danyel Cardoso Martins ${ }^{1}$; José Maurício Ferreira Neto ${ }^{1}$; \\ Maíra Moreira dos Santos ${ }^{1}$; João Luis Garcia ${ }^{1}$; Italmar Teodorico Navarroº \\ Emília Kiyomi Kuroda²; Roberta Lemos Freire ${ }^{1 *}$
}

\begin{abstract}
${ }^{1}$ Departamento de Medicina Veterinária Preventiva, Universidade Estadual de Londrina - UEL, Londrina, PR, Brasil
${ }^{2}$ Departamento de Construção Civil, Universidade Estadual de Londrina - UEL, Londrina, PR, Brasil
\end{abstract}

Received February 13, 2015

Accepted March 31, 2015

\begin{abstract}
The purpose of this study was to investigate the occurrence of Cryptosporidium spp. and Giardia spp. in a public water-treatment system. Samples of raw and treated water were collected and concentrated using the membrane filtration technique. Direct Immunofluorescence Test was performed on the samples. DNA extraction using a commercial kit was performed and the DNA extracted was submitted to a nested-PCR reaction (n-PCR) and sequencing. In the immunofluorescence, $2 / 24$ (8.33\%) samples of raw water were positive for Giardia spp.. In n-PCR and sequencing, 2/24 (8.33\%) samples of raw water were positive for Giardia spp., and 2/24 (8.33\%) samples were positive for Cryptosporidium spp.. The sequencing showed Cryptosporidium parvum and Giardia duodenalis DNA. In raw water, there was moderate correlation among turbidity, color and Cryptosporidium spp. and between turbidity and Giardia spp.. The presence of these protozoans in the water indicates the need for monitoring for water-treatment companies.
\end{abstract}

Keywords: Sequencing DNA, nested Polymerase Chain Reaction, protozoa, water supply.

\section{Resumo}

O objetivo deste estudo foi investigar a ocorrência de Cryptosporidium spp. e Giardia spp. em um sistema público de tratamento de água. Amostras de água bruta e tratada foram coletadas e concentradas, utilizando-se a técnica de filtração em membranas. Foi realizada a técnica de Imunofluorescência Direta nas amostras. A extração de DNA foi realizada, utilizando-se um kit comercial, e o DNA extraído foi submetido a uma reação de nested-PCR (n-PCR). Na imunofluorescência, 2/24 (8,33\%) amostras de água bruta foram positivas para Giardia spp.. Na n-PCR, 2/24 (8,33\%) amostras de água bruta foram positivas para Giardia spp., e 2/24 (8,33\%) amostras foram positivas para Cryptosporidium spp.. O sequenciamento demonstrou DNA de Cryptosporidium parvum e de Giardia duodenalis. Na água bruta, houve correlaçáo moderada entre turbidez, cor e Cryptosporidium spp. e entre a turbidez e Giardia spp.. A presença desses protozoários na água indica a necessidade de monitoramento pelas empresas de tratamento de água.

Palavras-chaves: Sequenciamento de DNA, nested Polymerase Chain Reaction, protozoário, abastecimento de água.

\section{Introduction}

Waterborne diseases caused by protozoans have a worldwide distribution in developed and developing countries and cause epidemics and endemic diseases in hum ans (COTRUVO et al., 2004). Cryptosporidiosis and giardiasis are the most prevalent parasitic diseases that cause waterborne diarrhea in humans (LANE \&

\footnotetext{
*Corresponding author: Roberta Lemos Freire. Departamento de Medicina Veterinária Preventiva, Universidade Estadual de Londrina - UEL, Rodovia Celso Garcia Cid, Pr 445 Km 380, Campus Universitário, CP 10.011, CEP 86057-970, Londrina, PR, Brasil.

e-mail: rlfreire@uel.br
}

LLOYD, 2002). Cryptosporidium spp. and Giardia spp. produce infectious forms (oocysts or cysts, respectively) that are transmitted by the feces of the infected host and are transmitted through direct contact with contaminated food or water (CACCIÒ et al., 2005; JEX et al., 2011). Molecular methods have identified different species and subtypes of these parasites (XIAO et al., 2001), many of which are infectious to humans (CHALMERS, 2011; FAYER, 2011).

Approximately 524 outbreaks worldwide have been recorded from waterborne diseases that are attributed to protozoans. Among the etiologic agents, Cyrptosporidium was responsible for 
$285(54.38 \%)$ of these outbreaks, followed by Giardia. which caused $202(34.58 \%)$ registered cases (BALDURSSON \& KARANIS, 2011).

In Brazil, the Ministry of Health Law 2914/11 outlines the procedures for the control and surveillance of water quality for human consumption and potability standards. This law determines that an annual geometric mean greater than or equal to 1,000 Escherichia coli/ $100 \mathrm{~mL}$ in raw water is necessary to monitor Giardia spp. cysts and Cryptosporidium spp. in different locations of the water catchment, with the goal of decreasing their occurrence (BRASIL, 2011).

There is a highest prevalence of waterborne protozoan infections in developing countries, due to their low hygiene standards, but there is no data that report the true occurrence of Cryptosporidium and Giardia in water supply sources. This lack of data leads to an underestimation of the real rate of waterbone parasite protozoan in developing countries (LIMA \& STAMFORD, 2003; BALDURSSON \& KARANIS, 2011).

Therefore, the purpose of this study was to investigate the occurrence of Cryptosporidium spp. and Giardia spp. in raw and treated water in a public water treatment system to perform a molecular characterization of isolates and to relate the results with physico-chemical and climate parameters.

\section{Materials and Methods}

\section{Study area of interest}

Londrina is the second largest city in Paraná State, Brazil, with a population of 537,566 residents (IBGE, 2013). Londrina is located between $23^{\circ} 08^{\prime} 47^{\prime \prime}$ and $23^{\circ} 55^{\prime} 46^{\prime \prime}$ South and between $50^{\circ} 52^{\prime} 23^{\prime \prime}$ and $51^{\circ} 19^{\prime} 11^{\prime \prime}$ West. The climate is humid subtropical, with precipitation in all seasons and an annual mean temperature of $21.6^{\circ} \mathrm{C}$ (LONDRINA, 2013).

There are two public water treatment systems (WTS) in Londrina; however, only one was chosen for this study. The chosen WTS performs the entire water treatment cycle (catchment, coagulation, flocculation, decantation, flotation, disinfection with chlorine, fluoridation, storage and distribution) and serves $32 \%$ of the city's population (SANEPAR, 2010).

The water is drawn from the Ribeirão Cafezal watershed. According to article 4 of Resolution No. 357 of 17 March 2005 of Conselho Nacional do Meio Ambiente (Conama), the water drawn from the Ribeirão Cafezal watershed, after conventional treatment, can be used for human consumption (BRASIL, 2005). The Ribeirão Cafezal watershed is located between $23^{\circ} 16^{\prime} 30^{\prime \prime}$ and $23^{\circ} 22^{\prime} 30^{\prime \prime}$ South and $51^{\circ} 11^{\prime} 40^{\prime \prime}$ and $51^{\circ} 23^{\prime} 30^{\prime \prime}$ West (PEREIRA \& LIMBERGER, 2002).

\section{Samples}

Samples of 100 liters of treated water and 30 liters of raw water were collected every two weeks between September 2012 and September 2013. The samples were stored in plastic containers and transported to the State University of Londrina.

\section{Water sample concentrations}

The samples were analyzed using a membrane-filtration technique with cellulose acetate membranes that had a $47 \mathrm{~mm}$ diameter and $1.2 \mu \mathrm{m}$ porosity (Millipore, Brazil). A vacuum pump system was used, and a filtration rate of 4 liters per minute was defined. The protocols followed those proposed by Dawson et al. (1993), Aldom \& Chagla (1995) and Cantusio \& Franco (2004).

\section{Direct immunofluorescence test}

We used $10 \mu \mathrm{L}$ aliquots of each sample to perform the direct immunofluorescence test using the Merifluor Cryptosporidium/Giardia commercial kit (Meridian Bioscience, USA) according to the manufacturer's protocol, using positive and negative controls. Simultaneously, a confirmatory test was performed with inclusion of the fluorogenic vital stain DAPI (4', $6^{\prime}$-diamidine-2-phenylindole; Sigma Chemicals Co., USA) to reveal the morphological characters (CANTUSIO \& FRANCO, 2004).

To read the immunofluorescence, we used a Nikon Eclipse epifluorescent microscope with a 450-490 nm excitation filter and a $520 \mathrm{~nm}$ emission filter. To read the DAPI, we used a 365-400 nm excitation filter and a $395 \mathrm{~nm}$ emission filter (REDLINGER et al., 2002). To identify oocysts and cysts, we used an immunofluorescence defined by a bright apple-green color, the absence of pores or appendices that had a compatible size and format: $8-12 \mu \mathrm{m}$ in size and an oval shape for Giardia spp. and 3-8.5 $\mu \mathrm{m}$ in diameter, a spherical shape and the presence (not necessary) of sutures in the oocyst for Cryptosporidium spp. (REDLINGER et al., 2002).

After enumerating the cysts and oocysts present in the samples, a formula proposed by Cantusio \& Franco (2004) was used to estimate the number of cysts and oocysts per liter.

\section{Nested-PCR for Cryptosporidium spp. and Giardia spp.}

All samples were subjected to DNA extraction using the NucleoSpin Tissue commercial kit (Macherey-Nagel, Germany), according to the manufacturer's protocol.

To detect the presence of Cryptosporidium spp., fragments of the 18S rRNA gene were amplified using a nested-PCR reaction. The first reaction primers (Invitrogen, Brazil) were SSU-F2 (5'-TTCTAGAGCTAATACATGCG-3') and SSU-R2 (5'- CCCATTTCCTTCGAAACAGGA-3'), which amplified a 1325 bp product (XIAO et al., 1999). The second reaction primers were SSU-F3 (5'- GGAAGGGTTGTATTTATTAGAT-3') and SSU-R4 (5'-AAGGAGTAAGGAACAACCTCCA-3'), generating a fragment of 819-825bp (XIAO et al., 1999). The detection threshold of the standardized technique was 10 oocysts / $\mathrm{ml}$.

A nested-PCR reaction was amplified to detect Giardia spp. fragments of the $16 \mathrm{~S} r \mathrm{RNA}$ gene. The first reaction primers (Invitrogen, Brazil) were Gia2029 (5'-AAGTGTGGTGCAGACGGACTC-3') and Gia2150c (5'-CTGCTGCCGTCCTTGGATGT-3'), which amplified a product of $497 \mathrm{bp}$ (APPELBEE et al., 2003). The second reaction primers were RH11 (5'-CATCCGGTCGATCCTGCC-3') and RH4 (5'-AGTCGAACCCTGATTCTCCGCCAGG-3'), which 
generated a fragment of 292-297 bp (HOPKINS et al., 1997). The detection threshold of the standardized technique was approximately 2 cysts / $\mathrm{ml}$.

The PCR products were subjected to electrophoresis on agarose gel (Invitrogen, Brazil) $1.5 \%$ stained with SYBR ${ }^{\circledR}$ Safe (Invitrogen, Brazil) for 45' for Cryptosporidium spp. and 30' for Giardia spp.. The products were visualized using ultraviolet light and photodocumented using the program LPix Image ST (Loccus Biotechnology, USA).

The positive bands were extracted from the gel and purified using the commercial kit QIAquick Gel Extraction. Sequencing was performed using an ABI3500 sequencer Genetic Analyzer (Applied Biosystems, USA), with the support of the BigDye Terminator v3.1 Cycle Sequencing commercial kit (Applied Biosystems, USA). Both forward and reverse strands were sequenced. The nucleotide sequences obtained were compared with the standard Cryptosporidium and Giardia sequences deposited in Genbank using the BLAST System (Basic Local Alignment and Search Tool) and by manual alignment using the BioEdit program (Biological Sequence Alignment Editor). The sequences obtained were deposited in Genebank under number KP334118 and KP334117 for Cryptosporidium and for Giardia under number KP334119 and KP334120.

\section{Physico-chemical parameters}

The turbidity was calculated using a $\mathrm{HACH}$ turbidimeter 2100Q, the $\mathrm{pH}$ was measured using a $\mathrm{pH}$ meter DM-Digimed 2P and the color was calculated using a $\mathrm{HACH}$ spectrophotometer DR/890 Colorimeter.

\section{Climate parameters}

Climate data (precipitation, relative humidity and temperature) were taken from the Instituto Agronômico do Paraná site (IAPAR, 2013).

\section{Statistical analysis}

To verify the correlation between the presence of Cryptosporidium spp. and Giardia spp. with water physico-chemical parameters and seasonality, the Pearson Correlation Coefficient (r) was calculated using the BioEstat 5.0 statistical package. The intensity correlation was defined as follows: weak $(0<\mathrm{r}<0.40)$, moderate $(0.40 \leq \mathrm{r}<0.7)$ and strong $(0.70 \leq \mathrm{r} \leq 1.0)$ (FIGUEIREDO \& SILVA, 2009).

\section{Results}

A total of 48 water samples, 24 raw and 24 treated, were analysed. Considering the results of the direct immunofluorescence, Cryptosporidium spp. was not detected in the raw or treated water samples. However, Giardia spp. was detected in 8.33\% (2/24) of the raw water samples and was absent in the treated water samples. The Giardia spp. concentrations were 0.42 cysts per liter and 4.2 cysts per liter.
According to the results of nested-PCR, Cryptosporidium spp. was present in $8.33 \%(2 / 24)$ of the raw water samples. In the nested-PCR, Giardia spp. was found in $8.33 \%(2 / 24)$ of the raw water. All treated water samples were negative for both parasites. These results were confirmed by means of sequencing, which showed $100 \%$ similarity to Cryptosporidium parvum (GenBank: KJ469985.1 and KP004204.1) and 100\% to Giardia duodenalis (GenBank: KJ027400.1 and AB569371.1)

For the physico-chemical parameters, the means [ \pm standard deviation] of the $\mathrm{pH}$, color and turbidity in the raw water were 9.55 $[ \pm 12.24], 250.54[ \pm 59.20]$ and 1198.85 [ \pm 59.26], respectively; the means in the treated water were $6.38[ \pm 0.22], 4.91[ \pm 1.23]$ and $0.40[ \pm 0.1]$, respectively. The means of the temperature, relative humidity and precipitation were $21.46[ \pm 4.17], 70.43$ [ \pm 4.16] and $13.51[ \pm 6.95]$, respectively.

Correlations were found between Cryptosporidium spp. presence and both color $(\mathrm{r}=0.4491, \mathrm{p}=0.0277)$ and turbidity $(\mathrm{r}=0.5422, \mathrm{p}=0.0061)$ and between Giardia spp. presence and turbidity $(\mathrm{r}=0.5809, \mathrm{p}=0.0029)$ (Table 1$)$.

\section{Discussion}

This study identified the presence of $C$. parvum and G. duodenalis in the water supply source studied. We obtained a similar result to those of other studies that have demonstrated the occurrence of protozoans in water supply sources in different regions around the world (NISHI et al., 2009b; CANTUSIO et al., 2010; JÚLIO et al., 2012; MAHMOUDI et al., 2013).

Genetic sequencing showed the presence of $C$. parvum in positive raw water samples. C. parvum is considered zoonotic because it has a lower host specificity, and it is thus of considerable interest to public health (FAYER, 2004). In China, Xiao et al. (2013) found oocysts of this parasite in $86.4 \%$ of water catchment areas and Lee et al. (2014) reported its prevalence in 23.1\% of Malaysian rivers. In Brazil, Araújo et al. (2011) described the occurrence of

Table 1. Pearson's Correlation Coefficient (r) between the physico-chemical and climate parameters for Cryptosporidium spp. and Giardia spp. in raw water from a public water treatment system in Londrina, Paraná, Brazil, September 2012 and September 2013.

\begin{tabular}{ccc}
\hline Parameters Analyzed & $\begin{array}{c}\text { Cryptosporidium } \\
\text { spp. }\end{array}$ & Giardia spp. \\
\hline $\mathrm{pH}$ & $\mathrm{p}=0.7535$ & $\mathrm{p}=0.7803$ \\
$\mathrm{r}=-0.0676$ & $\mathrm{r}=-0.0600$ \\
Color & $\mathrm{p}=0.0277$ & $\mathrm{p}=0.0621$ \\
& $\mathrm{r}=0.4491^{*}$ & $\mathrm{r}=0.3863$ \\
Turbidity & $\mathrm{p}=0.0061$ & $\mathrm{p}=0.0029$ \\
& $\mathrm{r}=0.5422^{*}$ & $\mathrm{r}=0.5809^{*}$ \\
Temperature & $\mathrm{p}=0.2929$ & $\mathrm{p}=0.0461$ \\
& $\mathrm{r}=0.2238$ & $\mathrm{r}=-0.4108$ \\
Humidity & $\mathrm{p}=0.9336$ & $\mathrm{p}=0.3328$ \\
& $\mathrm{r}=-0.0179$ & $\mathrm{r}=0.2065$ \\
Precipitation & $\mathrm{p}=0.6157$ & $\mathrm{p}=0.6157$ \\
& $\mathrm{r}=-0.1079$ & $\mathrm{r}=-0.1079$ \\
\hline
\end{tabular}

*significant correlation. 
this parasite in $30 \%$ of the water samples collected in state of São Paulo, whereas Osaki et al. (2013) found Cryptosporidium spp. in 2/4 of the water catchment systems in Curitiba, Paraná State.

Different studies involving the molecular analysis and sequencing of positive samples for Cryptosporidium spp. have been conducted with the goal of better understanding the environmental epidemiology of this parasite. Many studies describe the occurrence of $C$. meleagridis, $C$. hominis, $C$. parvum and $C$. andersoni in water samples (ARAÚJO et al., 2011; LEE et al., 2013; RUECKER et al., 2013).

It is also possible to quantify the degree of water contamination using direct immunofluorescence. It was observed concentrations of Giardia spp. cysts of 0.42 cysts per liter and 4.2 cysts per liter in two samples of raw water. The infectious dose for humans is relatively low: 10 cysts can begin an infection (STEINER et al., 1997).

Genetic sequencing showed the presence of $G$. duodenalis in positive raw water samples. There are six known species of Giardia, but only $G$. duodenalis has a wide host range and is the only species of interest to public health (THOMPSON \& MONIS, 2004), highlighting the importance of the findings of this study. Giardia spp. have a significant public health impact because, in addition to the prevalence and disease treatment costs, it can cause large outbreaks and affect the growth and cognitive development of children (FENG \& XIAO, 2011).

Descriptions of the occurrence of Giardia spp. in water samples have been reported. It has been found in $92.3 \%$ of river water, $55.5 \%$ of water reservoirs and $45.2 \%$ and $26.9 \%$ of raw water from small and conventional water treatment companies, respectively, and in $19.2 \%$ of small water treatment systems and $26.8 \%$ of tap water from municipalities that performed only water chlorination (CARMENA et al., 2007).

Sequencing positive water samples for Giardia spp. has also been conducted to determine the species involved: $G$. duodenalis has been described in cisterns containing drinking water and in an outbreak of diarrhea in humans due to the consumption of contaminated drinking water (AHMED et al., 2010; CHEUN et al., 2013).

In recent years, interest has grown in the zoonotic transmission of C. parvum and $G$. duodenalis, especially in relation to their transmission caused by cattle and other livestock (COKLIN et al., 2007). This finding explains the occurrence of both protozoans in the sources examined because many dairy cattle reside along the Ribeirão Cafezal, until it arrives at the WTS analyzed.

This study found a moderate correlation between the Cryptosporidium spp. presence and both color and turbidity in raw water and between Giardia spp. presence and turbidity in raw water. Correlations between the parameters analyzed and the presence of Cryptosporidium spp. and Giardia spp. were also described by Ahmad et al. (1997), Cantusio \& Franco (2004), Lopes (2009) and Nishi et al. (2009a). Low turbidity values are fundamental to obtaining better performance in the disinfection process inside water treatment systems (CERQUEIRA, 2008).

High concentrations of these two protozoa in raw water have been correlated with high concentrations or frequent detections in treated water. Thus, monitoring raw water should be an important tool for controlling and monitoring treated water quality (HELLER et al., 2004). Furthermore, Cryptosporidium and Giardia are refractory to the conventional treatments used in water treatment plants, which makes them even more important to public health (KARANIS et al., 2007). Thus, it is critically important to determine any sources of contamination and maintain water quality (FAYER, 2004; THOMPSON \& MONIS, 2004; AUSTIN et al., 2012).

The United States Environmental Protection Agency (USEPA) proposed Method 1623 to detect Cryptosporidium and Giardia in water. It is internationally recognized for its elevated efficiency. Method 1623 includes concentration phases, immunomagnetic separation and immunofluorescence microscopy (USEPA, 2005). However, at the present moment, there is not a globally preferred method for detecting Cryptosporidium and Giardia in water (FREGONESI et al., 2012).

In conclusion, this is the first report of the occurrence of $C$. parvum and $G$. duodenalis in the water supply of Londrina, Paraná State, Brazil. The circulation of Cryptosporidium spp. and Giardia spp. in the study area enhances the necessity for water treatment companies to comply with Ministry of Health Law No. 2914/11 to ensure a safe water supply for the population and avoid possible future waterborne outbreaks and negative impacts on public health.

\section{Acknowledgements}

We thank the Companhia de Saneamento do Paraná for their availability and the help offered during the development of this research.

\section{References}

Ahmad RA, Lee E, Tan ITL, Mohamad-Kamel AG. Occurrence of Giardia cysts and Cryptosporidium oocysts in raw and treated water from two water treatment plants in Selangor, Malaysia. Water Res 1997; 31(12): 3132-3136. http://dx.doi.org/10.1016/S0043-1354(97)00164-4.

Ahmed W, Vieritz A, Goonetilleke A, Gardner T. Health risk from the use of roof-harvested rainwater in Southeast Queensland, Australia, as potable or nonpotable water, determined using quantitative microbial risk assessment. Appl Environ Microbiol 2010; 76(22): 7382-7391. http:// dx.doi.org/10.1128/AEM.00944-10. PMid:20851954.

Aldom JE, Chagla AH. Recovery of Cryptosporidium oocysts from water by a membrane filter dissolution method. Lett Appl Microbiol 1995; 20(3): 186-187. http://dx.doi.org/10.1111/j.1472-765X.1995. tb00423.x. PMid:7766079.

Appelbee AJ, Frederick LM, Heitman TL, Olson ME. Prevalence and genotyping of Giardia duodenalis from beef calves in Alberta, Canada. Vet Parasitol 2003; 112(4): 289-294. http://dx.doi.org/10.1016/S03044017(02)00422-3. PMid:12623208.

Araújo RS, Dropa M, Fernandes LN, Carvalho TT, Sato MI, Soares RM, et al. Genotypic characterization of Cryptosporidium hominis from water samples in Sao Paulo, Brazil. Am J Trop Med Hyg 2011; 85(5): 834838. http://dx.doi.org/10.4269/ajtmh.2011.10-0449. PMid:22049036.

Austin Z, Alcock RE, Christley RM, Haygarth PM, Heathwaite AL, Latham SM, et al. Policy, practice and decision making for zoonotic disease management: water and Cryptosporidium. Environ Int 2012; 40: 70-78. http://dx.doi.org/10.1016/j.envint.2011.11.006. PMid:22280930. 
Baldursson S, Karanis P. Waterborne transmission of protozoan parasites: review of worldwide outbreaks - an update 2004-2010. Water Res 2011; 45(20): 6603-6614. http://dx.doi.org/10.1016/j.watres.2011.10.013. PMid:22048017.

Brasil. Conselho Nacional do Meio Ambiente - CONAMA. Resolução No. 357, de 17 de março de 2005. Dispóe sobre a classificação dos corpos de água e diretrizes ambientais para o seu enquadramento, bem como estabelece as condiçôes e padróes de lançamento de efluentes, e dá outras providências. Brasília; 2005 [cited 2014 Dec 15]. Available from: http://www.mma. gov.br/port/conama/legiabre.cfm?codlegi $=459$.

Brasil. Ministério da Saúde. Portaria No. 2914/11: estabelece o monitoramento dos parâmetros de gosto e odor, saxitoxina, cistos de Giardia spp. e oocistos de Cryptosporidium spp. Brasília; 2011 [cited 2014 Dec 15]. Available from: http://diariooficial.imprensaoficial.com.br/doflash/prototipo/2014/ Dezembro/11/exec1/pdf/pg_0099.pdf.

Cacciò SM, Thompson RC, McLauchlin J, Smith HV. Unravelling Cryptosporidium and Giardia epidemiology. Trends Parasitol 2005; 21 (9): 430-437. http://dx.doi.org/10.1016/j.pt.2005.06.013. PMid:16046184.

Cantusio R No, Franco RMB. Ocorrência de oocistos de Cryptosporidium spp. e cistos de Giardia spp. em diferentes pontos do processo de tratamento de água em Campinas, São Paulo, Brasil. Hig Aliment 2004; 118: 52-59.

Cantusio R No, Santos LU, Sato MI, Franco RM. Cryptosporidium spp. and Giardia spp. in surface water supply of Campinas, southeast Brazil. Water Sci Technol 2010; 62(1): 217-222. http://dx.doi.org/10.2166/ wst.2010.312. PMid:20595774.

Carmena D, Aguinagalde X, Zigorraga C, Fernández-Crespo JC, Ocio JA. Presence of Giardia cysts and Cryptosporidium oocysts in drinking water supplies in northern Spain. J Appl Microbiol 2007; 102(3): 619-629. http://dx.doi.org/10.1111/j.1365-2672.2006.03193.x. PMid:17309610.

Cerqueira DA. Remoção de oocistos de Cryptosporidium parvum e de indicadores no tratamento de água por ciclo completo, filtração direta descendente e dupla filtração, em escala piloto [Dissertaçáo]. Belo Horizonte: Universidade Federal de Minas Gerais; 2008.

Chalmers R. The importance of unusual Cryptosporidium species and genotypes in human cryptosporidiosis [online]. Swansea: GIG/NHS; 2011 [cited 2014 Aug 10]. Available from: http://water.epa.gov/lawsregs/rulesregs/ sdwa/lt2/upload/importanceofunusualcrypto.pdf.

Cheun HI, Kim CH, Cho SH, Ma DW, Goo BL, Na MS, et al. The first outbreak of giardiasis with drinking water in Korea. Osong Public Health Res Perspect 2013; 4(2): 89-92. http://dx.doi.org/10.1016/j. phrp.2013.03.003. PMid:24159537.

Coklin T, Farber J, Parrington L, Dixon B. Prevalence and molecular characterization of Giardia duodenalis and Cryptosporidium spp. in dairy cattle in Ontario, Canada. Vet Parasitol 2007; 150(4): 297-305. http:// dx.doi.org/10.1016/j.vetpar.2007.09.014. PMid:17964724.

Companhia de Saneamento do Paraná-SANEPAR. Gerência metropolitana de Londrina - relatório de gestão - nivel II [online]. Londrina: SANEPAR; 2010 [cited 2014 Aug 5]. Available from: http://www.pnqs.com.br/ arquivos/rgs/sanepar_londrina.pdf.

Cotruvo JA, Durfour A, Rees G, Bartram J, Carr R, Cliver DO, et al. Waterborne zoonoses: identification, causes and control. London: World Health Organization; IWA Publishing; 2004.

Dawson DJ, Maddocks M, Roberts J, Vidler JS. Evaluation of recovery of Cryptosporidium parvum oocysts using membrane filtration. Lett Appl Microbiol 1993; 17(6): 276-279. http://dx.doi.org/10.1111/j.1472765X.1993.tb01465.x.
Fayer R. Cryptosporidium: a water-borne zoonotic parasite. Vet Parasitol 2004; 126(1-2): 37-56. http://dx.doi.org/10.1016/j.vetpar.2004.09.004. PMid:15567578.

Fayer R. Species and genotypes of Cryptosporidium [online]. Beltsville: USDA Agricultural Research Service; 2011 [cited 2014 Aug 10]. Available from: http://water.epa.gov/lawsregs/rulesregs/sdwa/lt2/upload/ speciesandgenotypesofcrypto.pdf.

Feng Y, Xiao L. Zoonotic potential and molecular epidemiology of Giardia species and giardiasis. Clin Microbiol Rev 2011; 24(1): 110-140. http:// dx.doi.org/10.1128/CMR.00033-10. PMid:21233509.

Figueiredo DB Fo., Silva JA Jr. Desvendando os mistérios do coeficiente de correlação de Pearson (r). Rev Política Hoje 2009; 18(1): 115-146.

Fregonesi BM, Sampaio CF, Ragazzi MF, Tonani KAA, Segura-Muñoz SI. Cryptosporidium e Giardia: desafios em águas de abastecimento público. O Mundo da Saúde 2012; 36(4): 602-609.

Heller L, Bastos RKX, Vieira MBCM, Bevilacqua PD, Brito LLA, Mota SMM, et al. Oocistos de Cryptosporidium e cistos de Giardia: circulação no ambiente e riscos à saúde humana. Epidemiol Serv Saúde 2004; 13(2): 79-92.

Hopkins RM, Meloni BP, Groth DM, Wetherall JD, Reynoldson JA, Thompson RC. Ribosomal RNA sequencing reveals differences between the genotypes of Giardia isolates recovered from humans and dogs living in the same locality. J Parasitol 1997; 83(1): 44-51. http://dx.doi. org/10.2307/3284315. PMid:9057695.

Instituto Agronômico do Paraná - IAPAR. Dados Diários de Londrina [online]. 2013 [cited 2014 Aug 10]. Available from: http://www.iapar. $\mathrm{br} /$ modules/conteudo/conteudo.php? conteudo $=1828$.

Instituto Brasileiro de Geografia e Estatística-IBGE. Cidades@ [online]. 2013 [cited 2014 Aug 10]. Available from: http://cidades.ibge.gov.br/ xtras/perfil.php?lang=\& codmun= 411370 .

Jex AR, Chalmers RM, Smith HV, Widmer G, McDonald V, Gasser RB. Cryptosporidiosis. In: Palmer SR, Soulsby L, Torgerson PR, Brown DWG, editors. Oxford textbook of zoonoses: biology, clinical practice, and public health control. New York: Oxford University Press; 2011. p. 536-538.

Júlio C, Sá C, Ferreira I, Martins S, Oleastro M, Angelo H, et al. Waterborne transmission of Giardia and Cryptosporidium at river beaches in Southern Europe (Portugal). J Water Health 2012; 10(3): 484-496. http://dx.doi. org/10.2166/wh.2012.030. PMid:22960492.

Karanis P, Kourenti C, Smith H. Waterborne transmission of protozoan parasites: a worldwide review of outbreaks and lessons learnt. J Water Health 2007; 5(1): 1-38. http://dx.doi.org/10.2166/wh.2006.002. PMid:17402277.

Lane S, Lloyd D. Current trends in research into the waterborne parasite Giardia. Crit Rev Microbiol 2002; 28(2): 123-147. http://dx.doi. org/10.1080/1040-840291046713. PMid:12109771.

Lee YT, Tsaihong JC, Tseng YC, Tsai CM, Peng SY. Development of PCR-RFLP method to distinguish between Cryptosporidium parvum and C. hominis in Taiwan water samples. Southeast Asian J Trop Med Public Health 2013; 44(1): 13-18. PMid:23682432.

Lee SC, Ngui R, Tan TK, Roslan MA, Ithoi I, Lim YA. Aquatic biomonitoring of Giardia cysts and Cryptosporidium oocysts in peninsular Malaysia. Environ Sci Pollut Res Int 2014; 21(1): 445-453. http://dx.doi. org/10.1007/s11356-013-1925-1. PMid:23794081. 
Lima EC, Stamford TLM. Cryptosporidium spp. no ambiente aquático: aspectos relevantes da disseminação e diagnóstico. Cien Saude Colet 2003 ; 8(3): 791-800. http://dx.doi.org/10.1590/S1413-81232003000300013.

Londrina. Prefeitura de Londrina [online]. 2013 [cited 2014 Aug 5]. Available from: http://www1.londrina.pr.gov.br.

Lopes AMMB. Avaliação da ocorrência de oocistos de Cryptosporidium spp.e de cistos de Giardia spp. e sua associação com indicadores bacteriológicos e turbidez na Represa de Vargem das Flores - MG [Dissertação]. Belo Horizonte: Universidade Federal de Minas Gerais; 2009.

Mahmoudi MR, Kazemi B, Mohammadiha A, Mirzaei A, Karanis P. Detection of Cryptosporidium and Giardia (oo)cysts by IFA, PCR and LAMP in surface water from Rasht, Iran. Trans $R$ Soc Trop Med Hyg 2013; 107(8): 511-517. http://dx.doi.org/10.1093/trstmh/trt042. PMid:23736273.

Nishi L, Baesso ML, Santana RG, Fregadolli P, Falavigna DL, FalavignaGuilherme AL. Investigation of Cryptosporidium spp. and Giardia spp. in a public water-treatment system. Zoonoses Public Health 2009a; 56(5): 221-228. http://dx.doi.org/10.1111/j.1863-2378.2008.01189.x. PMid:19068074.

Nishi L, Bergamasco R, Toledo MJO, Falavigna DLM, Gomes ML, Mota LT, et al. Giardia spp. and Cryptosporidium spp. In the Ivaí Indigenous Land, Brazil. Vector Borne Zoonotic Dis 2009b; 9(5): 543-547. http:// dx.doi.org/10.1089/vbz.2008.0021. PMid:18945186.

Osaki SC, Soccol VT, Costa AO, Oliveira-Silva MB, Pereira JT, Procópio AE. Polymerase chain reaction and nested-PCR approaches for detecting Cryptosporidium in water catchments of water treatment plants in Curitiba, State of Paraná, Brazil. Rev Soc Bras Med Trop 2013; 46(3): 270-276. http://dx.doi.org/10.1590/0037-8682-0053-2013. PMid:23856874.

Pereira OC No, Limberger L. Estudo da adequabilidade do uso do solo na área rural, através de técnicas de geoprocessamento. Geografia (Londrina) 2002; 11(2): 171-183.
Redlinger T, Corella-Barud V, Graham J, Galindo A, Avitia R, Cardenas V. Hyperendemic Cryptosporidium and Giardia in households lacking municipal sewer and water on the United States-Mexico border. $A m J$ Trop Med Hyg 2002; 66(6): 794-798. PMid:12224594.

Ruecker NJ, Matsune JC, Lapen DR, Topp E, Edge TA, Neumann NF. The detection of Cryptosporidium and the resolution of mixtures of species and genotypes from water. Infect Genet Evol 2013; 15: 3-9. http://dx.doi. org/10.1016/j.meegid.2012.09.009. PMid:23088833.

Steiner TS, Thielman NM, Guerrant RL. Protozoal agents: what are the dangers for the public water supply? Annu Rev Med 1997; 48: 329-340. http://dx.doi.org/10.1146/annurev.med.48.1.329. PMid:9046966.

Thompson RCA, Monis PT. Variation in Giardia: implications for taxonomy and epidemiology. Adv Parasitol 2004; 58: 69-137. http:// dx.doi.org/10.1016/S0065-308X(04)58002-8. PMid:15603762.

United States Environmental Protection Agency - USEPA. Method 1623: Cryptosporidium and Giardia in Water by Filtration/IMS/FA. Cincinnati: USEPA; 2005. [cited 2014 Dec 15]. Available from: www.epa.gov/ microbes/documents/1623de05.pdf.

Xiao L, Morgan UM, Limor J, Escalante A, Arrowood M, Shulaw W, et al. Genetic diversity within Cryptosporidium parvum and related Cryptosporidium species. Appl Environ Microbiol 1999; 65(8): 3386-3391. PMid:10427023.

Xiao L, Singh A, Limor J, Graczyk TK, Gradus S, Lal A. Molecular characterization of Cryptosporidium oocysts in samples of raw surface water and wastewater. Appl Environ Microbiol 2001; 67(3): 1097-1101. http://dx.doi.org/10.1128/AEM.67.3.1097-1101.2001. PMid:11229897.

Xiao G, Qiu Z, Qi J, Chen JA, Liu F, Liu W, et al. Occurrence and potential health risk of Cryptosporidium and Giardia in the Three Gorges Reservoir, China. Water Res 2013; 47(7): 2431-2445. http://dx.doi. org/10.1016/j.watres.2013.02.019. PMid:23478072. 